\title{
Effect of Varying Inclusion Levels of Fossil Shell Flour on Growth Performance, Water Intake, Digestibility and $\mathrm{N}$ Retention in Dohne-Merino Wethers
}

\author{
Olusegun O Ikusika ${ }^{1,2, * \mathbb{C}}$, Conference T. Mpendulo ${ }^{1}$, Titus $\mathrm{J}_{\text {Zindove }}{ }^{3}$ and \\ Anthony I Okoh 2,4 (D) \\ 1 Department of Livestock and Pasture Science, Faculty of Science and Agriculture, University of Fort Hare, \\ Alice 5700, South Africa \\ 2 SAMRC Microbial Water Quality Monitoring Centre, University of Fort Hare, Alice 5700, South Africa \\ 3 Department of Animal Science, Faculty of Agriculture and Environmental Science, Bindura University of \\ Science Education, Bindura 263, Zimbabwe \\ 4 Applied and Environmental Microbiology Research Group (AEMREG), Department of Biochemistry and \\ Microbiology, University of Fort Hare, Alice 5700, South Africa \\ * Correspondence: pastorikusika@gmail.com
}

Received: 29 July 2019; Accepted: 6 August 2019; Published: 16 August 2019

Simple Summary: With the recent negative public opinion on chemical-based feed additive in many nations of the world (for the health implication and environmentally hazard it posed), naturally occurring feed additive are urgently needed to replace and support the sustainable development in livestock production. The potential of Fossil shell flour as performance enhancer was investigated in this study. The major finding was that fossil shell flour increased growth performance, apparent nutrient digestibility, $\mathrm{N}$ retention and make minimum use of water in Dohne-Merino wethers. Hence it could be an alternative to chemical-based feed additive in livestock production.

\begin{abstract}
This study was carried out to determine the effect of varying levels of Fossil shell flour (FSF) supplementation on growth performance, water intake, digestibility and $\mathrm{N}$ retention in Dohne Merino sheep pursuant to establishing the optimum inclusion rate of this supplement in Dohne Merino diets. Sixteen Dohne-Merino wethers ( $18 \pm 1.5 \mathrm{~kg}$ body weight) were used in a complete randomized design with four animals per treatment. Sheep were fed a basal diet without FSF addition (control, T1), or with the addition of FSF $(2 \%, \mathrm{~T} 2),(4 \%, \mathrm{~T} 3)$ or $(6 \%, \mathrm{~T} 4)$ of the diet for 105 days. Treatment $3(4 \%$ FSF) has the highest values of dry matter intake, total weight gain, $\mathrm{N}$ retention and for most of the apparent digestibility nutrients (CP, EE and Ash) compared to treatment T1, T2 and T4 $(p<0.05)$. The urinary and fecal $\mathrm{N}$ excretion also significantly decreased in the FSF treated diets compared to the control $(p<0.05)$. Water intake values were highest in control and were significantly $(p<0.05)$ different from those in treatments 2 and 4 , but not to treatment 3 . It is concluded that $4 \%$ inclusion rate of FSF will give the best improvement on growth performance, diet digestibility and $\mathrm{N}$ retention of Dohne-Merino sheep. Also, the addition of FSF in the diets of sheep is a safe natural additive that can help to reduce environmental pollution by reducing fecal and urinary $\mathrm{N}$ excretion.
\end{abstract}

Keywords: Fossil shell flour; growth performance; digestibility; nitrogen utilization; Dohne-Merino

\section{Introduction}

The use of growth promoters in farm animal diets is growing at an increasing rate [1]. Growth promoters are used to improve feed efficiency and the growth performance of farm animals. Rumen regulation through the use of growth promoters is one of the most important methods for 
improving feed efficiency and, thus, growth performance. Likewise, feed additives in ruminant's nutrition has the potential to increase dry matter intake (DMI), feed conversion efficiency (FCE) and animal productivity [1,2]. There is a wide range of feed additives that include antibiotics, probiotics, antioxidants, enzymes, prebiotics, organic acids, mycotoxin binders, hormones, beta agonist, defaunation agents, essential oil and herbal feed additives, most of which are chemical based [2].

Although the use of growth promoters as feed additives has been a hallmark of modern animal husbandry, in recent years there have been increased concerns on chemical residues in meat and other animal products as a result of these chemical based feed additives [3,4]. There is also increase in ecological risk because of the accumulation of veterinary antibiotics residue in animal manure [5], bodies of water, sediments and soils [6,7]. Arikan [8] reported that antibiotics administered to farm animals either as growth promoter or medication were usually excreted without metabolism. Similarly, [9] observed that between 70 to $90 \%$ of tetracycline may be excreted as parent compounds through urine or feaces.

Because of the possible risks of chemical-based growth promoters, there have been increased interest in natural growth promoters (NGPs). Several plants and plant extracts, enzymes, organic acids and oils have received considerable attention recently as possible NGPs that are eco-friendly [10]. One of the major drawbacks to the use of these NGPs is the time and cost involved in harvesting them. One NGP that could be useful as a cost effective, readily available, health and eco-friendly feed additive is Fossil shell flour. Fossil shell flour is a naturally occurring silicate rich substance with important physical and chemical characteristics that enable its uses recently as feed additive in livestock production. The substance is nontoxic, cheap, and readily available in large quantity in many countries [11]. The mineral constituent of dietary fossil shell flour as reported by [12-14] are as follows: Sodium, 923 mg/kg; Copper, 30 mg/kg; Zinc, 118 mg/kg; Iron, 7944 mg/kg; Magnesium, 69 mg/kg; Calcium, 0.22\%; Magnesium, 0.11\%; Potassium, 0.08\%; Aluminum, 0.065\%; Sulfate sulphate, $0.062 \%$, Boron, $23 \mathrm{mg} / \mathrm{kg}$, and Vanadium, $438 \mathrm{mg} / \mathrm{kg}$.

In the study conducted by Emeruwa et al. [15] using West Africa dwarf sheep, it was observed that inclusion of Fossil shell flour in the diet statistically affected the average daily weight gain with the highest value $(0.20 \mathrm{~kg} /$ day) observed for the sheep fed the $4 \%$ inclusion level of Fossil shell flour and the lowest value of $(0.11 \mathrm{~kg} /$ day) for those on $6 \%$ inclusion of fossil shell flour. Likewise, Sarijit et al., [16] reported that addition of diatomaceous earth (another name for FSF) to animal feeds ( $3.2 \%$ inclusion) improve daily feed intake, weight gain and feed efficiency.

On the effects of FSF on digestibility, [15] Emeruwa, (2016) observed that crude protein (\%) digestibility was significantly higher (82.79) for sheep on $4 \%$ inclusion level of fossil shell flour than other levels. This author also reported that although $\mathrm{N}$ intake and the fecal and urinary $\mathrm{N}$ excretion were not significantly different among the treatment groups, $\mathrm{N}$ retention ( $\% \mathrm{~N}$ intake) was significantly higher $(72.4 \%)$ for sheep on $2 \%$ inclusion level of Fossil shell flour than for the other groups.

There is paucity of information on feedlot performance of Dohne-Merino supplemented with varying levels of FSF, and no reports are available on the effect of FSF on the water intake of Dohne-Merino. Considering that the use of this feed additive is cost effective, health and eco-friendly, the objective of this study was to assess the effects of 4 levels of FSF inclusion on growth performance, water intake, digestibility and $\mathrm{N}$ retention of Dohne-Merino sheep. We hypothesized that the inclusion of FSF at varying levels could increase the growth performance, digestibility and $\mathrm{N}$ retention of Dohne-Merino sheep.

\section{Materials and Methods}

\subsection{Ethical Approval}

The handling and the use of the animals was approved by University of Fort Hare, Animal ethics and Use Committee [Approval number (MPE041IKU01)]. 


\subsection{Study Site Description}

The experiment was conducted at the small ruminant unit of the University of Fort Hare teaching and research farm (animal section), Alice, Eastern Cape, South Africa. The research farm is located at about Km 5 along Alice-Kings Williams town, which lies at longitude $26^{\circ} 50^{\prime} \mathrm{E}$ and latitude of $32^{\circ} 46^{\prime}$ $\mathrm{S}$. The annual rainfall is between $480-490 \mathrm{~mm}$ and temperature range between $24.6^{\circ} \mathrm{C}$ and $11.1^{\circ} \mathrm{C}$ (average is $17.8^{\circ} \mathrm{C}$ ) at the altitude of $535 \mathrm{~m}$ above sea level.

\subsection{Animal, Experimental Design and Management}

Sixteen Dohne-Merino wethers (6 months old) weighing $20 \pm 1.5 \mathrm{~kg}$ on average were selected from a commercial farm in Mitford village Tarkastad, Eastern Cape of South Africa, and were used for this study in a completely randomized design. All the 16 wethers were raised at the same facility in the same area under the same environmental conditions (University of Fort Hare, Teaching and Research Farm, Animal Section, Alice 5700, RSA). The wethers were randomly allotted into four treatment $(n=4)$. They were individually housed $(1.5 \mathrm{~m} \times 1.5 \mathrm{~m})$ in a well-ventilated roofed animal building with concrete floor. The pens have similar temperature, relative humidity and sunlight conditions. The experiment lasted for 105 days, excluding 14 days of adaptation period. The animals have access to sufficient clean and fresh water over the trial.

\subsection{Experimental Diets}

The diets for the animals consisted of concentrate and hay at 40:60 ratio. The concentrate was made up of maize $(8 \%)$, sunflower oil cake $(10 \%)$, molasses $(5 \%)$, wheat offal $(15 \%)$, limestone $(1.5 \%)$, salt $0.3 \%$ and sheep mineral-vitamin premix $(0.2 \%)$, whereas the hay consisted of $30 \%$ teff and $30 \%$ Lucerne. All ingredients were thoroughly milled and mixed evenly together to form the basal diet. The feed was formulated to meet the nutritional (energy and protein) requirements of the used sheep [17]. The four dietary groups were: T1: Basal diet (Control); T2: Basal diet $+2 \%$ FSF; T3: Basal diet $+4 \%$ FSF, and T4: Basal diet $+6 \%$ FSF. The animals were fed at 8:00 $\mathrm{h}$ and $15: 00 \mathrm{~h}$ at $4 \%$ of the body weight (on dry matter (DM) basis). The Fossil shell flour (Food - Grade) was purchased from Eco-Earth (Pty) Ltd., Port Elizabeth, SA which produces this product under a license by Department of Agriculture, Forestry and Fisheries of South Africa.

\subsection{Analytical Procedures}

Dry matter content of the diets, orts and fecal samples was measured by drying samples in an air-forced oven at $135^{\circ} \mathrm{C}$ for $24 \mathrm{~h}$ (method 930.15; [18]) Ash content was measured by placing samples into a muffle furnace at $550{ }^{\circ} \mathrm{C}$ for $5 \mathrm{~h}$ (method 938.08; [18]. Organic matter (OM) was measured as the difference between DM and the ash content. Nitrogen $(\mathrm{N})$ was measured by the Kjeldahl method using Se as a catalyst and crude protein $(\mathrm{CP})$ was calculated as $6.25 \times$ N. Gross energy (GE) was measured using a bomb calorimeter (C200, IKA Works Inc., Staufen, Germany). Ether extracts (EE) were measured by weight loss of the DM on extraction with diethyl ether in Soxhlet extraction apparatus for $8 \mathrm{~h}$ (method 920.85) [18]. Crude fibre was determined by allowing the sample to boil with $1.25 \%$ dilute $\mathrm{H}_{2} \mathrm{SO}_{4}$, washed with water, further boiled with $1.25 \%$ dilute sodium hydroxide and the remaining residue after digestion was taken as crude fibre (method 978.10) as described by Thiex [19].

\subsection{Feed Intakes and Growth Performance}

During the 105 days of feeding trial, data on feed offered to each animal and the corresponding orts were recorded daily to estimate voluntary intake of DM and nutrients. Samples of feeds offered and orts were oven dried at $65^{\circ} \mathrm{C}$ until a constant weight to determine DM concentration, and then ground to pass through 1-mm sieve (Wiley mill; Thomas Scientific, Philadelphia, PA, USA) and analyzed for organic matter (OM), CP, EE and CF by the procedures described above. The body weight (BW) of animals was individually recorded at the beginning of the trial, on weekly basis throughout the trial, 
and at the end of the experiment before the morning feeding. Feed intake, average daily gain (ADG) and feed efficiency were calculated from the data obtained.

\subsection{Apparent Nutrients Digestibility and N Retention}

Apparent digestibility coefficients of DM, OM, CP, EE and CF were determined by the total fecal collection method [20]. On day 91, 3 animals per treatment were placed into individual metabolism crates $(0.5 \mathrm{~m} \times 1.2 \mathrm{~m})$, allowing feces and urine to be collected. The digestibility trial lasted for 14 days with 7 days for adaptation to metabolism crates and 7 days for the sample collection.

The amount of feed offered, refused, and feces were weighed daily and homogenized. A 10\% sample of total feces was collected during a 7-day collection period as described by Ma et al. [21]. Urine was collected daily in buckets containing $100 \mathrm{~mL}$ of $10 \%(\mathrm{v} / \mathrm{v}) \mathrm{H}_{2} \mathrm{SO}_{4}$. The volume was measured and a sample ( $10 \%$ of total volume) was collected and stored at $-20{ }^{\circ} \mathrm{C}$ until analysis. Samples of feed, orts, feces, and urine were pooled to form a composite sample for each wether. Urinary $\mathrm{N}$ was analyzed by the Kjeldahl method [18], and $\mathrm{N}$ retention was calculated as daily $\mathrm{N}$ excretion (urinary $\mathrm{N}$ plus fecal N) subtracted from daily $\mathrm{N}$ intake.

\subsection{Statistical Analysis}

The data on apparent digestibility and $\mathrm{N}$ retention were analyzed using the PROC MIXED of SAS (version 9.1; SAS Inst. Inc., Cary, NC, USA). Because the experimental design was completely randomized, the model included only the fixed effect of the diet (treatment). Repeated measures were used to analyze data on feed and water intake and growth parameters. The effects of diet (treatment), weeks, and their interactions were considered fixed, whereas the wether was considered random. Data are presented as mean \pm standard error of the mean, and significant differences were accepted if $p<$ 0.05 , Orthogonal polynomial contrasts were used to test the linear and quadratic effects of the diet on the parameters measured.

\section{Results and Discussion}

\subsection{Chemical Composition of the Experimental Diets}

The chemical composition of the basal experimental diets is shown in Table 1.

Table 1. Ingredients and chemical composition of the basal diet fed to Dohne-Merino sheep.

\begin{tabular}{cc}
\hline Items & Percentage (\%) \\
\hline Maize & 8 \\
Sunflower oil cake & 10 \\
Molasses & 5 \\
Wheat bran & 15 \\
Limestone & 1.6 \\
Salt & 0.20 \\
Sheep mineral-vitamin premix & 0.30 \\
Grinded Lucerne hay & 30 \\
Grinded teff hay & 30 \\
Chemical composition & \\
Dry Matter (\% as fed) & 95.5 \\
Organic Matter (\%DM) & 85.2 \\
Energy (MJ/kg DM) & 24.7 \\
Crude Protein (\% DM) & 14.6 \\
Ash (\%DM) & 10.3 \\
Ether Extract & 1.70 \\
Crude Fibre & 22.60 \\
\hline
\end{tabular}




\subsection{Feed and Water Intake}

As shown in Table 2, the inclusion of FSF in the diet of Dohne-Merino wethers had a significant effect $(p<0.05)$ on feed intake. Animals in Treatments 3 and 4 consumed more feed than animals in the control group (linear $p=0.04$; quadratic $p=0.02$ ) while animals in treatment 2, consumed the least feed. This shows that the addition of FSF to the diets of Dohne-Merino wethers at $4 \%$ inclusion rate will increase the daily feed intake. This is similar to the results obtained by Emeruwa et al. [15], who recorded the lowest feed intake in the group fed $2 \%$ of FSF (900 $\pm 9.0 \mathrm{~g} / \mathrm{d}$ ) and the highest value for the $6 \%$ inclusion group $(1009 \pm 9.0 \mathrm{~g} / \mathrm{d})$. Also, Mclean et al. [22] reported significant variations in the feed intake of calves fed varying levels of FSF. Sheep requires about 25 to 40 ounces per head per day of $\mathrm{NaCl}$, and will eat less feed when deprived of $\mathrm{NaCl}[23,24]$. Similarly, it has been observed that minerals such as $\mathrm{Na}, \mathrm{Ca}, \mathrm{K}$ and $\mathrm{Mg}$ increase the palatability of the diet and the feed intake of the animal $[25,26]$. This could be the reason why animals fed FSF-supplemented diets had greater feed intakes compared with the controls, because FSF had been reported to be rich in minerals, including $\mathrm{Na}$ (923 ppm), Ca (0.22\%), Mg (0.11\%) and K (0.11\%) [12-14]. Feed efficiency was highest in T3 while the control treatment has the lowest value $(p<0.05)$. However, the control was not statistically different from T2 and T4. The greater feed intake in T3 group was especially notable from week 7 until the end of the trial (Figure 1). The absence of quadratic effect observed for various inclusion levels of FSF on nutrients intake shows that adding increasing levels of FSF up to $6 \%$ inclusion levels of the diets DM had no adverse effects on their consumption by the animals.

Table 2. Effects of varying levels of FSF on growth performance and water intake on Dohne-Merino wethers.

\begin{tabular}{cccccccc}
\hline Parameter & \multicolumn{3}{c}{ Level of FSF in Diet (\% of DM) } & \multicolumn{2}{c}{ SEM } & \multicolumn{2}{c}{$\boldsymbol{P}$-Values } \\
\hline & $\mathbf{0}$ & $\mathbf{2}$ & $\mathbf{4}$ & $\mathbf{6}$ & & Linear & Quadratic \\
\hline Feed Intake(g) & 593 & 572 & 694 & 648 & 39.9 & 0.045 & 0.024 \\
Feed Efficiency (g/g) & 0.14 & 0.18 & 0.19 & 0.17 & 0.01 & 0.011 & 0.023 \\
ADG (g/d) & 84.7 & 92.9 & 121.4 & 105.4 & 9.53 & 0.000 & 0.011 \\
Water Intake (L) & 1.95 & 1.67 & 1.8 & 1.45 & 0.10 & 0.000 & 0.113 \\
Initial Weight (Kg) & 19.2 & 19.4 & 19.5 & 19.4 & 0.43 & 0.667 & 0.221 \\
Final Weight (Kg) & 28.0 & 28.6 & 31.3 & 29.7 & 0.48 & 0.043 & 0.322 \\
Total Weight Gain (Kg) & 8.32 & 9.20 & 12.0 & 10.3 & 0.38 & 0.042 & 0.232 \\
\hline
\end{tabular}

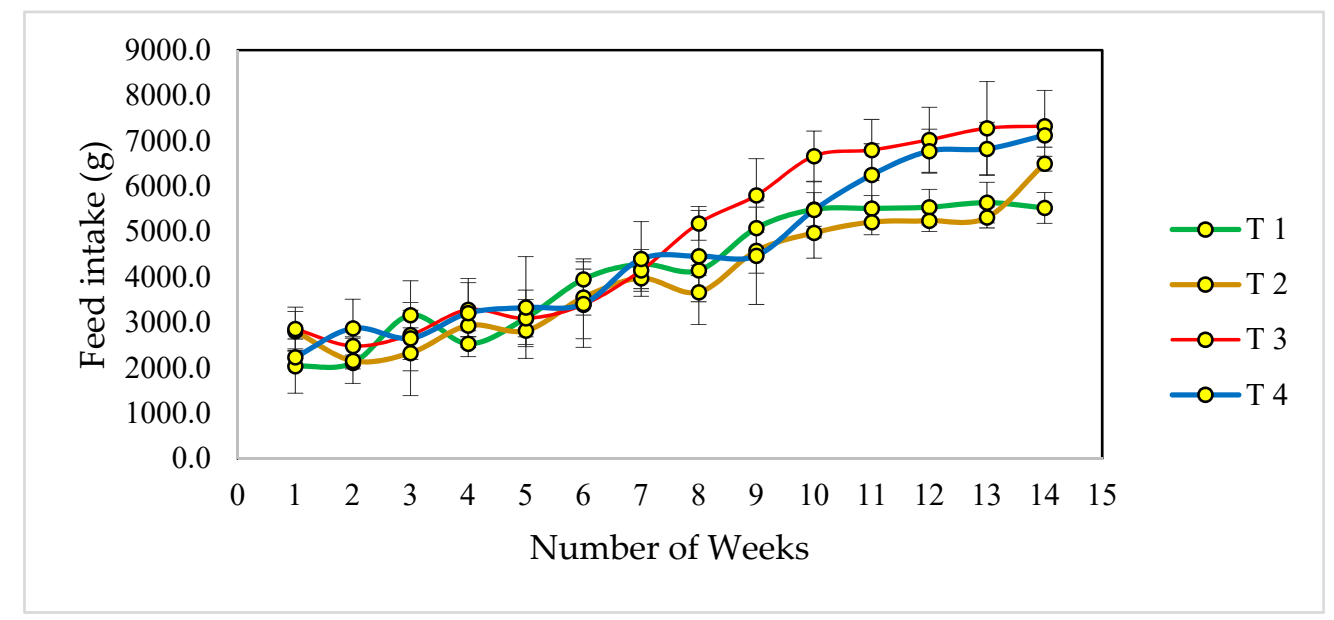

Figure 1. Graphical representation of feed intake of Dohne-Merino wethers fed varying levels of Fossil shell flour (FSF) shown as means \pm standard errors. T1: 0\% FSF diet; T 2: 2\% FSF diet; T3: 4\% FSF diet; T4: 6\% FSF diet. 
The water intake decreased linearly $(p<0.001)$ as the inclusion levels of FSF increased in the diets, except for $4 \%$ inclusion level (Table 2). The control group has the greatest water intake, while T4 has the lowest value. Although the control group consumed slightly more water than T3 group, differences were not significant $(p>0.05)$. Increased water intakes usuallly encourage sheep to eat more feed $[27,28]$.

\subsection{Growth Performance}

The effects of varying inclusion levels of FSF on growth performance are shown in Table 2. Average daily weight gain was increased (linear $p=0.00$; quadratic $p=0.01$ ) and final weight was greater (linear $p=0.04$ ) with increasing inclusion levels of FSF. The ADG was lowest for control group and greatest for T3. The lowest ADG and final BW in the control group (T1) is in agreement with the lower DMI recorded in the trial for this group.

\subsection{Nitrogen Utilization and Nutrients Apparent Digestibility.}

Table 3 shows the nitrogen utilization and diet apparent digestibility in Dohne-Merino rams fed varying levels of FSF. Nitrogen intake, urinary $\mathrm{N}$ and $\mathrm{N}$ balance were not affected by the levels of FSF inclusion. However, fecal $\mathrm{N}$ was decreased (linear $p=0.03$; quadratic, $p=0.03$ ) as inclusion levels of FSF increased. This indicates that FSF could be used to reduce environmental pollution through reduction in fecal $\mathrm{N}$ excretion. This result was similar to the report obtained by Rajabi et al. [29] using pomegranate peel extract in fattening lambs as feed supplement. Vallejo et al. [30] reported that addition of natural feed additive such as xylanase (at $3 \mu \mathrm{L} / \mathrm{g}$ ) to the diets of sheep could reduce excretion of $\mathrm{N}$ through fecal and urine.

Table 3. Nitrogen utilization (g/d) and apparent digestibility (\%) of Dohne Merino fed varying levels of Fossil shell flour.

\begin{tabular}{|c|c|c|c|c|c|c|c|}
\hline \multirow[t]{2}{*}{ Parameter } & \multicolumn{4}{|c|}{ Level of FSF in Diet,\% of DM } & \multirow[t]{2}{*}{ SEM } & \multicolumn{2}{|c|}{$P$-Values } \\
\hline & 0 & 2 & 4 & 6 & & Linear & Quadratic \\
\hline \multicolumn{8}{|l|}{ N Retention(g/d) } \\
\hline N Intake & 9.83 & 11.07 & 13.96 & 10.24 & 0.44 & 0.433 & 0.954 \\
\hline Fecal N & 1.94 & 1.31 & 1.23 & 1.48 & 0.47 & 0.033 & 0.033 \\
\hline Urinary $\mathbf{N}$ & 0.79 & 0.32 & 0.41 & 0.58 & 0.07 & 0.856 & 0.842 \\
\hline N Balance & 7.15 & 9.41 & 12.35 & 8.18 & 0.46 & 0.454 & 0.965 \\
\hline \multicolumn{8}{|c|}{ Apparent Digestibility (\%) } \\
\hline Dry Matter & 64.50 & 63.83 & 72.92 & 62.83 & 2.74 & 0.375 & 0.311 \\
\hline Organic Matter & 65.58 & 66.24 & 73.15 & 63.13 & 2.81 & 0.353 & 0.367 \\
\hline Crude Protein & 70.62 & 81.83 & 85.24 & 77.16 & 1.65 & 0.192 & 0.011 \\
\hline Ether Extract & 85.54 & 89.69 & 93.01 & 90.19 & 1.41 & 0.247 & 0.222 \\
\hline Crude Fibre & 51.10 & 51.17 & 64.79 & 52.73 & 3.88 & 0.712 & 0.312 \\
\hline
\end{tabular}

The linear positive effect of the treatment on daily retained $\mathrm{N}$ in the present study was similar to that reported by Soroor et al. [31] when fattening Mehraban lambs were fed Echium amoenum extract up to $1.5 \mathrm{~mL} / \mathrm{kg}$ of diet DM. Conversely, this result was not in agreement with the result observed by Emeruwa et al. [15] using FSF as supplement in West African dwarf sheep, as they observed that $\mathrm{N}$ retention was greater in control compared to the treatments. However, both in this study and in the study reported by Adebiyi et al. [12], FSF has no significant effect on $\mathrm{N}$ balance and $\mathrm{N}$ retention. The differences among studies could be due to different experimental conditions. This study was conducted in a semi-arid region while Emeruwa et al. conducted their trial in a tropical region. Other factors, as dietary and breed differences could have also influenced the results.

Increasing the inclusion levels of FSF had no effects on DM, OM, EE, and CF digestibility (Table 3), but it has a quadratic effect on apparent CP digestibility $(p=0.01)$. The diet supplemented with $4 \%$ FSF (T3) showed the greatest value for all nutrient's digestibility and was significantly different $(p<$ 
$0.05)$ from the control (T1) for all nutrients. However, there were no differences $(p>0.05)$ among T2, $\mathrm{T} 3$ and $\mathrm{T} 4$ treatments for $\mathrm{CP}$ and EE digestibility (Table 3 ). These results indicate that FSF enhanced the absorption of amino acids by the animal and thereby making them available at tissue levels [32]. These results are contrary to those obtained by Emeruwa et al. [15], who found that West African Dwarf sheep fed diets containing FSF at the same levels of inclusion than in the present study had numerically greater $\mathrm{CP}$ and $\mathrm{EE}$ digestibility values for control compared to other treatments, although differences did not reach the statistical significance. This difference in the results could be due to differences in breeds and diets composition. The lack of influence of FSF on DM, OM, EE and CF, may be attributed to similar digestibility of the experimental diets, particularly crude fibre digestibility [33]. Additionally, the relative similarity in the physical characteristics of the experimental diets may be the reason(s) for lack of no intake differences among the experimental sheep, because physical and nutrients composition of diets affect the feed intake [34].

\section{Conclusions}

The results from this study showed that adding $4 \%$ FSF to the diets of Dohne-Merino wethers gives a better improvement than other levels of FSF inclusion on DMI, feed efficiency, ADG, total weight gain, $\mathrm{N}$ retention and apparent nutrient digestibility of most of the nutrients. In addition, the wethers on this treatment consumed the lowest volume of water. These results suggested that inclusion of FSF at $4 \%$ in the diet could be potentially used as a performance enhancer.

Author Contributions: Ikusika, O.O.I. conceived, planned, and carried out research work, C.T.M., T.J.Z., and A.I.O. reviewed and supervised the research work and the manuscript. A.I.O. provided funds for the research.

Funding: This research work was made possible by the financial support from South Africa Medical Research Council.

Acknowledgments: The authors are grateful to University of Fort Hare for providing necessary facilities for the research work.

Conflicts of Interest: The authors declare that there is no conflict of interest in the submission of this manuscript.

\section{References}

1. Frater, P. Feed Additives in Ruminant Nutrition2014;Published by Agriculture and Horticulture Development Board, England (EBLEX). 2014.

2. Chaturvedi, I.; Dutta, T.K.; Singh, P.K.; Sharma, A.; Kumar, M.; Rao, B. Effect of Herbal Feed Additives on IVDMD, Methane and Total Gas Production Via in-vitro Study. J. Agroecol. Nat. Resour. Manag. 2014, 1, $108-112$.

3. Tedeschi, L.O.; Callaway, T.R.; Muir, J.P.; Anderson, R.C. Potential environmental benefits of feed additives and other strategies for ruminant production. Rev. Bras. Zootec. 2011, 40, 291-309.

4. Jalaal, M.; Balmforth, N.J.; Stoeber, B. Slip of Spreading Viscoplastic Droplets. Langmuir 2015, 31, 12071-12075. [CrossRef] [PubMed]

5. Li, Y.X.; Zhang, X.L.; Li, W.; Lu, X.F.; Liu, B.; Wang, J. The residues and environmental risks of multiple veterinary antibiotics in animal faeces. Environ. Monit. Assess. 2013, 185, 2211-2220. [CrossRef] [PubMed]

6. Hu, X.; Zhou, Q.; Luo, Y. Occurrence and source analysis of typical veterinary antibiotics in manure, soil, vegetables and groundwater from organic vegetable bases, northern China. Environ. Pollut. 2010, 158, 2992-2998. [CrossRef] [PubMed]

7. Watanabe, N.; Bergamaschi, B.A.; Loftin, K.A.; Meyer, M.T.; Harter, T. Watanabe Use and environmental occurrence of antibiotics in freestall dairy farms. Environ. Sci. Technol. 2010, 44, 6591-6600. [CrossRef] [PubMed]

8. Arikan, O.A.; Mulbry, W.; Rice, C. Management of antibiotic residues from agricultural sources: Use of composting to reduce chlortetracycline residues in beef manure from treated animals. J. Hazard. Mater. 2009, 164, 483-489. [CrossRef] 
9. Pils, J.R.V. The Role of Soil Clays and Clay-Humic Complexes in Processes Controlling Colloidal Stability and the Sorption and Degradation of Tetracyclines Recommended Citation. Ph.D. Thesis, Iowa State University, Ames, IA, USA, 2005.

10. Valero, M.V.; Do Prado, R.M.; Zawadzki, F.; Eiras, C.E.; Madrona, G.S.; Do Prado, I.N. Propolis and essential oils additives in the diets improved animal performance and feed efficiency of bulls finished in feedlot. Acta Sci. Anim. Sci. 2014, 36, 419-426. [CrossRef]

11. Ikusika, O.O.; Mpendulo, C.T.; Zindove, T.J.; Okoh, A.I. Fossil Shell Flour in Livestock Production: A Review. Animals 2019, 9, 70. [CrossRef] [PubMed]

12. Adebiyi, O.A.; Sokunbi, O.A.; Ewuola, E.O. Performance Evaluation and Bone Characteristics of Growing Cockerel Fed Diets Containing Different Levels of Diatomaceous Earth. Middle East J. Sci. Res. 2009, 4, 36-39.

13. Adeyemo, G.O. Growth performance of broiler chicken fed Fossil shell flour growth promoter. Food Nutr. Sci. 2013, 4, 26622.

14. Lakkawar, A.W.; Sathyanarayana, M.L.; Narayanaswamy, H.D.; Sugunarao, O.; Yathiraj, S. Efficacy of diatomacious earth in amelioration of aflatoxin induced toxicity in broiler chicken. Indian J. Anim. Res. 2016, 50, 529-536. [CrossRef]

15. Emeruwa, C.H. Growth Performance of West African Dwarf Sheep Fed Diets Supplemented with Fossil Shell Flour. Ph.D. Thesis, University of Ibadan, Ibadan, Nigeria, 2016.

16. Sarijit, J.; Steve, S.; Micheal, E.; Rodney, D. Animal Feed Compositions Including Spent Filter Media Containing Diatomaceous Earth. US Patent US20160295884A1, 13 October 2016.

17. National Research Council (NRC). Nutrient Requeriments of Small Ruminants: Sheep, Goats, Cervids, and New World Camelids; National Academy of Sciences: Washington, DC, USA, 2007.

18. Association of Officiating Analytical Chemists (AOAC). Official Method of Analysis Association of Officiating Analytical Chemist, 18th ed.; Association of Officiating Analytical Chemists: Washington, DC, USA, 2005.

19. Nancy, J. Thiex Evaluation of Analytical Methods for the Determination of Moisture, Crude Protein, Crude Fat, and Crude Fiber in Distillers Dried Grains with Solubles. J. AOAC Int. 2009, 92, 61-73.

20. Gebrehiwot, G.; Negesse, T.; Abebe, A. Effect of Feeding Leucaena leucocephala Leaves and Pods on Feed Intake, Digestibility, body Weight Change and Carcass Characteristic of Central-Highland Sheep Fed basal Diet Wheat bran and Natural Pasture Hay in tigray, Ethiopia. Int. J. Agric. Environ. Biotechnol. 2017, 10, 367. [CrossRef]

21. Ma, G.W.; Chu, Y.K.; Zhang, W.J.; Qin, F.Y.; Xu, S.S.; Yang, H.; Rong, E.G.; Du, Z.Q.; Wang, S.Z.; Li, H.; et al. Polymorphisms of FST gene and their association with wool quality traits in Chinese Merino sheep. PLoS ONE 2017, 12, e0174868. [CrossRef] [PubMed]

22. McLean, B.; Frost, D.; Evans, E.; Clarke, A.; Griffiths, B. The inclusion of diatomaceous earth in the diets of grazing ruminants and its effect on gastrointestinal parasite burdens. In Proceedings of the International Scientific Conference on Organic Agriculture, Adelaide, Australia, International Scientific Conference of Organic Agriculture Research, Bonn, Germany, 21-23 September 2005.

23. Digby, S.N.; Chadwick, M.A.; Blache, D. Salt intake and reproductive function in sheep. Animal 2011, 5, 1207-1216. [CrossRef] [PubMed]

24. Van, P. An Award-wining Merino sheep enterprise with the use of diatomaceous earth. Farmer's Wkly. 2015, 30, 1-15.

25. Garmyn, A.J.; Hilton, G.G.; Mateescu, R.G.; Morgan, J.B.; Reecy, J.M.; Tait, R.G., Jr.; Beitz, D.C.; Duan, Q.; Schoonmaker, J.P.; Mayes, M.S.; et al. Estimation of relationships between mineral concentration and fatty. J. Anim. Sci. 2011, 89, 2849-2858. [CrossRef]

26. Desimone, J.A.; Beauchamp, G.K.; Drewnowski, A.; Johnson, G.H. Sodium in the food supply: Challenges and opportunities. Nutr. Rev. 2013, 71, 52-59. [CrossRef]

27. Prasetiyono, B.W.H.E.; Sunagawa, K.; Shinjo, A.; Shiroma, S. Physiological relationship between thirst level and feed intake in goats fed on alfalfa hay cubes. J. Anim. Sci. 2000, 13, 1536-1541. [CrossRef]

28. Abioja, M.O.; Osinowo, O.A.; Adebambo, O.A.; Bello, N.J.; Abiona, J.A. Water restriction in goats during hot-dry season in the humid tropics: Feed intake and weight gain Nigerian livestock industries experience. Arch. Zootec. 2010, 59, 195-203. [CrossRef]

29. Rajabi, M.; Rouzbehan, Y.; Rezaei, J. A strategy to improve nitrogen utilization, reduce environmental impact, and increase performance and antioxidant capacity of fattening lambs using pomegranate peel extract. J. Anim. Sci. 2017, 95, 499-510. [CrossRef] [PubMed] 
30. Vallejo, L.H.; Salem, A.Z.M.; Camacho, L.M.; Kholif, A.M.; Mariezcurrena, M.D.; Cipriano, M.; Alonso, M.U.; Olivares, J.; Lopez, S. Effects of xylanase supplementation on feed intake, digestibility and ruminal fermentation in Rambouillet sheep. J. Agric. Sci. 2016, 154, 1110-1117. [CrossRef]

31. Soroor, E.N.; Rouzbehan, Y.; Alipour, D. Effect of Echium amoenum extract on the growth rate and fermentation parameters of mehraban lambs. Anim. Feed Sci. Technol. 2013, 184, 49-57. [CrossRef]

32. Bahrami-yekdangi, M.; Ghorbani, G.R.; Khorvash, M.; Khan, M.A.; Ghaffari, M.H. Reducing crude protein and rumen degradable protein with a constant concentration of rumen undegradable protein in the diet of dairy cows: Production performance, nutrient digestibility, nitrogen efficiency, and blood metabolites. J. Anim. Sci. 2015, 94, 1-8. [CrossRef] [PubMed]

33. Van Soest, P.J. Nutritional Ecology of the Ruminant, 2nd ed.; Cornell University Press: Ithaca, NY, USA, 1994.

34. Riaz, M.Q.; Südekum, K.H.; Clauss, M.; Jayanegara, A. Voluntary feed intake and digestibility of four domestic ruminant species as influenced by dietary constituents: A meta-analysis. Livest. Sci. 2014, 162, 76-85. [CrossRef]

(C) 2019 by the authors. Licensee MDPI, Basel, Switzerland. This article is an open access article distributed under the terms and conditions of the Creative Commons Attribution (CC BY) license (http://creativecommons.org/licenses/by/4.0/). 